\title{
Web-Based Gamification Loaded E-Learning Information System For Junior High Schools
}

\section{Sistem Informasi E-Learning Bermuatan Gamifikasi Berbasis Web Untuk Sekolah Menengah Pertama}

\author{
Muhammad Reza Pahlevi ${ }^{1}$, Ika Ratna Indra Astutik ${ }^{2}$ \\ \{reza.bromo1@gmail.com¹,ikaratna@umsida.ac.id²
}

Universitas Muhammadiyah Sidoarjo, Jl. Raya Gelam No. 250 Sidoarjo. 61271 Indonesia

\begin{abstract}
Currently teaching and learning activities are carried out using E-learning facilities, E-learning is a means of teaching and learning activities from school to college. E-learning itself is now one of the standard learning methods in several schools and gamification is needed to support e-learning so that users are interested in its use. Gamification itself implements in-game features into a non-game context such as points, badges, and leaderboard. The method used in this research is the waterfall method which this method plans a system from upstream to downstream. In terms of appearance, this website looks attractive in for its users. This system is easy to use, so it is easier for students to do learning even though they are at home. The result of this research is that students can learn anywhere using available devices.
\end{abstract}

Keywords - E-learning; Gamification; Waterfall; Web

\begin{abstract}
Abstrak. Saat ini kegiatan belajar mengajar dilakukan menggunakan sarana E-learning, E-learning merupakan suatu sarana kegiatan belajar mengajar mulai jenjang sekolah sampai perkuliahan. E-learning sendiri sekarang menjadi salah satu standar metode pembelajaran di beberapa sekolah, dan gamifikasi diperlukan untuk menunjang e-learning ini supaya pengguna tertarik dalam penggunaannya. Gamifikasi sendiri mengimplementasikan fitur dalam game ke dalam sebuah konteks non-game misalnya poin, lencana dan leaderboard. Metode yang digunakan dalam penelitian ini yakni metode waterfall yang dimana metode ini merencanakan sebuah sistem dari hulu ke hilir. Dalam segi tampilan, website ini terlihat menarik bagi penggunanya. Sistem ini mudah digunakan, sehingga dapat mempermudah siswa dalam melakukan pembelajaran walaupun sedang berada di rumah. Hasil dari penelitian ini adalah siswa dapat belajar di mana pun menggunakan perangkat yang tersedia.
\end{abstract}

Kata Kunci-E-learning; Gamifikasi; Waterfall; Web

\section{Pendahuluan}

E-learning merupakan suatu sarana kegiatan belajar mengajar di sekolah maupun perkuliahan. E-learning sendiri sekarang menjadi salah satu standar metode pembelajaran di beberapa sekolah dari jenjang Sekolah Dasar, Sekolah Menengah Pertama, Sekolah Menengah Atas dan jenjang perkuliahan. Penerapan E-learning pada dunia pendidikan beberapa tahun belakang menjadi popular dikarenakan adanya pandemi covid-19. Namun pada SMP Negeri 1 Krembung belum menggunakan sarana E-learning dalam kegiatan belajar mengajar di era pandemi ini.

E-Learning merupakan salah satu sarana yang paling umum digunakan oleh instansi Pendidikan di Indonesia. $E$ learning merupakan sistem pembelajaran elektronik yang mencakup berbagai jenis media yang dapat memberikan dan menampilkan teks, gambar, dokumen dan pembelajaran berbasis komputer, extranet atau berbasis website [1]. Dari pernyataan ini, dapat dipahami bahwa E-learning memiliki kelebihan dibandingkan sistem konvensional yakni menghemat waktu proses belajar mengajar, mengurangi biaya perjalanan, menjangkau wilayah geografis yang lebih luas dan sebagainya [5].

Secara umum saat ini kegiatan belajar mengajar dilakukan menggunakan sarana E-learning. Pada observasi awal, ditemukan bahwa SMP Negeri 1 Krembung belum mempunyai E-learning dan perlu adanya pembuatan sistem ini. Oleh karena itu E-learning ini perlu memiliki sebuah fitur yang menarik bagi siswa/siswi seperti fitur dalam game. Salah satu fitur game yang dapat diterapkan adalah gamifikasi. Dan dalam pembuatan website sendiri membutuhkan bootstrap, PHP, MySQL dan Framework Codeigniter.

Menurut Jusuf, gamifikasi adalah menggunakan unsur mekanik game untuk memberikan solusi praktikal dengan cara menggunakan ketertarikan (engagement) kelompok tertentu [2]. Sedangkan menurut Meyhart, Gamifikasi adalah penggunaan elemen-elemen game dan teknik design game dalam konteks non-game. Elemen game yaitu seperti poin, lencana, tingkatan, narasi dan sebagainya. tapi seiring perkembangan inti dari gamifikasi saat ini adalah bagaimana untuk membangun motivasi [3]. Penggunaan gamifikasi saat ini telah diterapkan secara luas di bidang non game/hiburan, melainkan digunakan juga untuk pendidikan dan dunia bisnis. 


\section{METODE}

\section{A. Metode waterfall}

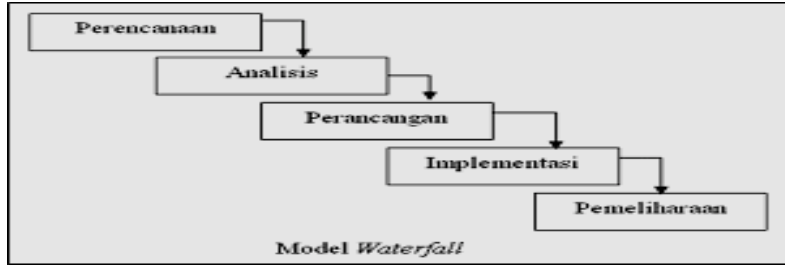

Gambar 1. Metode Waterfall

Metode yang digunakan dalam penelitian ini yakni metode waterfall, metode waterfall sendiri merupakan metode pengerjaan dari suatu sistem yang di mana pengerjaannya dilakukan secara berurutan dan mendetail, sehingga Dalam perancangan nya harus diselesaikan secara bertahap dan penuh. Sebelum melanjutkan ke tahap selanjutnya agar tidak terjadi pengulangan tahapan dan bisa membuat kualitas dari softwere yang dibuat tetap terjaga dan pemeliharaannya pun lebih mudah [4]. Dan perancangan sistem ini dilakukan dengan berurutan seperti dijelaskan pada gambar 1

\section{B. Flowchart}

Flowchart merupakan suatu bagan dengan simbol-simbol tertentu yang menggambarkan urutan proses secara mendetail dan hubungan antara suatu proses atau instruksi dengan proses lainnya dalam suatu program. Flowchart hanya untuk menyederhanakan rangkaian proses untuk memudahkan pemahaman pengguna terhadap informasi tersebut. Flowchart bisa untuk segala sesuatu yang mengandung rangkaian kegiatan. Flowchart menggunakan simbol yang ter-standarisasi secara internasional. Hal ini bertujuan untuk mempermudah orang untuk memahami berbagai variasi flowchart.

\section{Perancangan sistem}

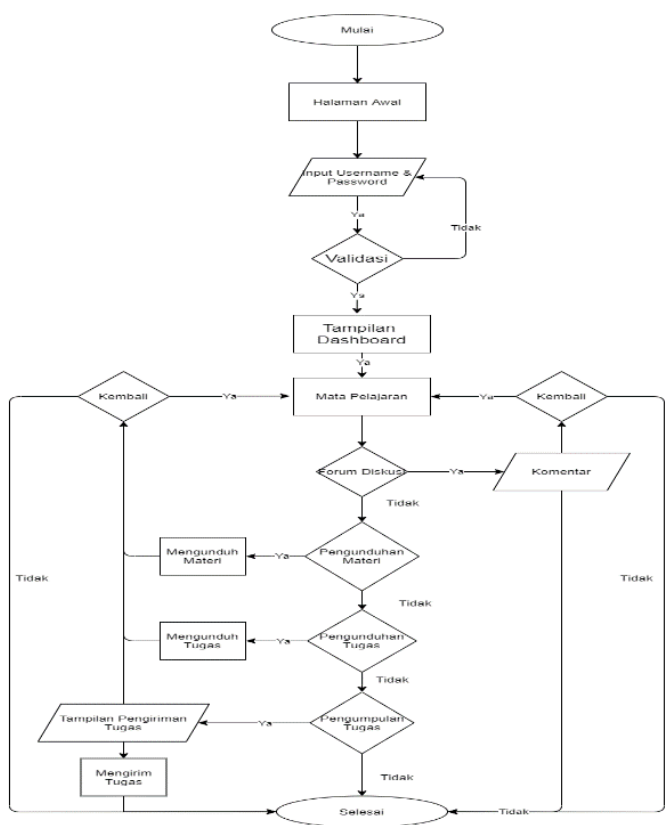

Gambar 2. Flowchart

Pada Gambar 2 menggambarkan alur sistem secara umum yang dimulai dari halaman awal yang bisa lanjut pada bagian login memasukkan username dan password yang nanti akan divalidasi oleh sistem terkait kebanaran username dan password. Jika salah, maka tampilan akan kembali pada menu login jika benar maka Selanjutnya setelah validasi akan memasuki tampilan dashboard setelah itu masuk pada mata pelajaran. Setelah masuk pada mata pelajaran, pengguna akan menemui kondisi “Apakah ingin mengikuti forum?". Jika pengguna memilih iya, maka sistem akan masuk ke dalam menu forum. Jika pengguna memilih tidak, maka sistem akan memasuki kondisi “Apakah ingin mengunduh materi?". Jika iya, maka materi akan diunduh dan sistem akan kembali ke menu mata pelajaran. Jika tidak, maka pengguna akan menemui kondisi “Apakah ingin mengunduh tugas?”. Jika iya, maka tugas akan diunduh dan sistem akan kembali ke menu mata pelajaran. Jika tidak, maka pengguna akan menemui 
kondisi “Apakah ingin mengunggah tugas?”. Jika iya, maka pengguna akan diminta mengunggah tugas. Jika tidak, maka sistem akan selesai.

\section{Boostrap}

Bootstrap merupakan salah satu framework CSS yang merupakan sumber terbuka dan bebas untuk merancang situs web. Kerangka kerja bootstrap berisikan tamplate desain berbasis HTML dan CSS, bootstrap diciptakan dengan tujuan mempercantik tampilan front-end dan menjadikan tampilan website menjadi responsive di ukuran layar mana pun.

Bootstrap juga merupakan framework yang dapat menyelesaikan permasalahan dalam mendesain web. Adapun slogan dari framework bootstrap "Sleek, intuitive, and powerful front-end framework for faster and easier web development", yang artinya "kita dapat mendesain sebuah website dengan lebih rapi, cepat dan mudah". Bootstrap juga responsive terhadap banyak platform yang artinya tampilan halaman website yang menggunakan bootstrap akan tampak tetap rapi [6].

\section{E. PHP}

Hypertext Preprocessor atau biasa disebut PHP merupakan suatu bahas pemrograman yang digunakan dalam dokumen HTML. Tujuan utama penggunaan PHP yaitu untuk memungkinkan perancangan web yang bersifat dinamis dan dapat bekerja secara otomatis. PHP merupakan salah satu bahasa pemrograman berbasis web yang memiliki kemampuan untuk memproses data secara dinamis [7]. PHP merupakan suatu bahasa pemrograman yang dapat digunakan untuk membuat halaman web dinamis. Dalam suatu halaman HTML dapat ditanamkan kode php yang akan dieksekusi setiap kali halaman terserbut di kunjungi [8].

\section{F. MySQL}

MySQL adalah software sistem manajemen data Base yang paling popular. MySQL Bersifat Lintas platform, hampir Sebagian besar aplikasi website yang ada di internet dikembangkan menggunakan MySQL. MySQL berlisensi open-source, menyediakan fitur yang lengkap, menggunakan bentuk setandar Bahasa data sql, mendukung banyak data Base, data disesuaikan dengan keinginan kita, dan bekerja dengan cepat dan baik [9].

\section{G. Codeigniter}

CodeIgniter (CI) merupakan framework PHP, metode yang digunakan oleh Framework CodeIgniter (CI) disebut Model - View - Controller (MVC). MVC memisahkan antara logika pemrograman dengan presentasi. Hal tersebut dapat terlihat dari adanya minimalis script presentasi (HTML, CSS, dan sebagainya) yang dipisahkan dari PHP. Di dalam folder CI, MVC dapat di temukan dalam folder application. CodeIgniter juga menjadi salah satu framework pilihan yang memungkinkan pengembang program untuk membuat sebuah web, yang memungkinkan untuk digunakan dan dikembangkan. CodeIgniter terdiri dari file-file library, kelas-kelas, dan infrastruktur runtime [10].

\section{HaSil dan Pembahasan}

\section{A. Implementasi sistem}

Berikut ini penulis menjelaskan bagaimana penggunaan sistem elearning bermuatan gamifikasi untuk siswa.

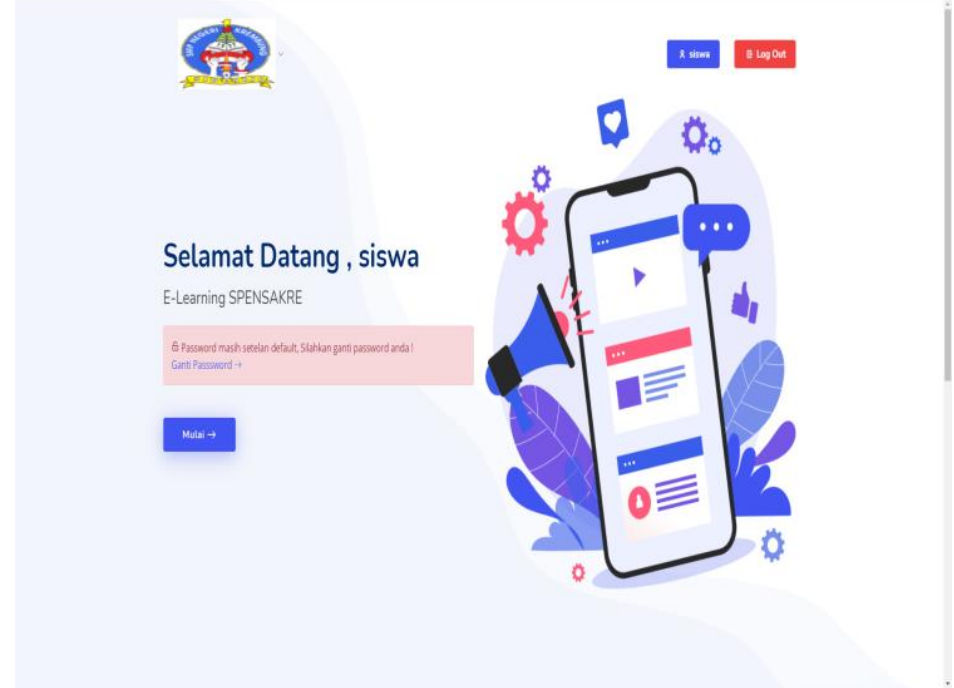

Gambar 3. Tampilan Halaman Awal Setelah Login 
Procedia of Engineering and Life Science Vol. 1. No. 2 Juni 2021

Seminar Nasional \& Call Paper Fakultas Sains dan Teknologi (SENASAINS $2^{\text {nd }}$ )

Universitas Muhammadiyah Sidoarjo
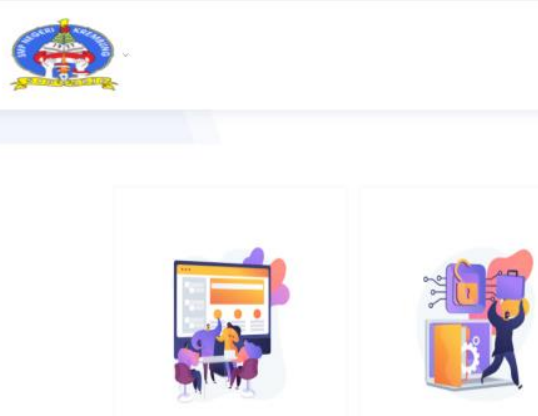

Mata pelajaran

Ganti Password

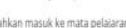

Wengegarti passourd atun

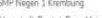

Gambar 4. Tampilan Halaman Awal Setelah Klik Tombol Mulai

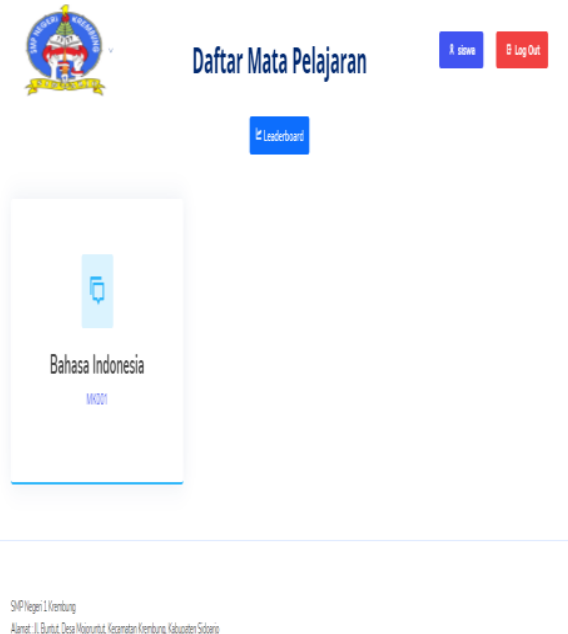

Gambar 5.Tampilan Setelah Memilih Mata Pelajaran

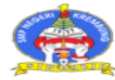

Leaderboard

8 isons on out
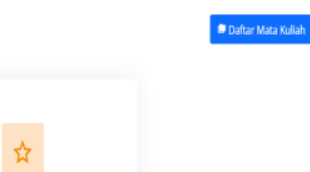

Bahasa Indonesia

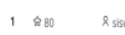

Gambar 6. Tampilan Setelah Memilih Leaderboard 


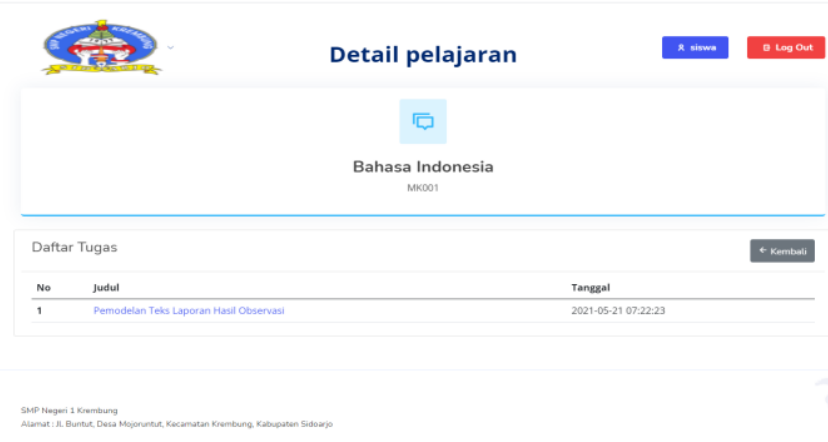

Gambar 7. Tampilan Detail Pelajaran Setelah Klik Mata Pelajaran Bahasa Indonesia

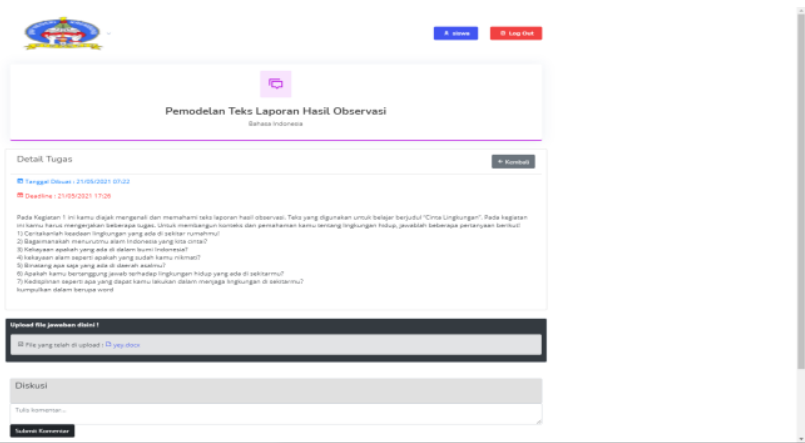

Gambar 8. Tampilan Mata Pelajaran

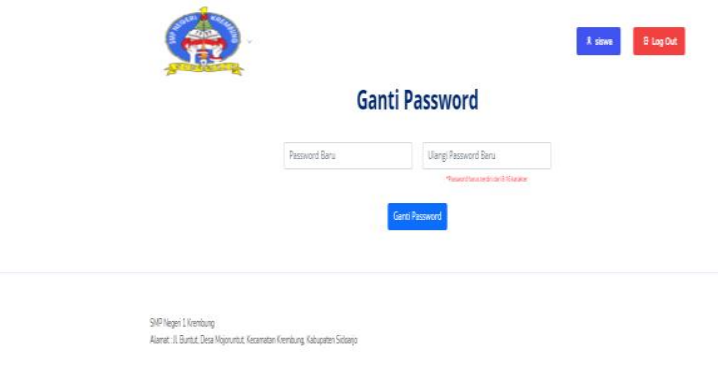

Gambar 9. Tampilan Jika Ingin Mengganti Password

Gambar 3 menampilkan halaman awal setelah melalui halaman login. Gambar 4 menampilkan bagian bawah pada halaman awal setelah mengeklik tombol mulai. Gambar 5 menampilkan daftar mata pelajaran yang tersedia padah halaman tersebut. Gambar 6 menampilkan leaderboard yang dimanah di situ ditampilkan kalkulasi dari hasil gamifikasi yang dimanah siswa mengumpulkan tugas dan memberikan diskusi. Gambar 7 menampilkan mata pelajaran yang ada. Gambar 8 menampilkan detail mata pelajaran Bahasa Indonesia. Gambar 9 menampilkan pilihan mengganti password.

\section{KESIMPULAN}

Kesimpulan yang didapat dari hasil perancangan sistem informasi e-learning bermuatan gamifikasi berbasis web untuk sekolah menengah pertama sebagai berikut: (1) Dengan adanya sistem ini dapat mempermudah siswa dalam melakukan pembelajaran walaupun sedang berada diramah. (2) Memiliki tampilan menarik bagi penggunanya (3) Mudah digunakan oleh pengguna, (4) gamifikasi yang diterapkan dalam sistem ini hanyalah berupa akumulasi poin yang akan ditampilkan dalam leaderboard yang dimanah semakin banyak siswa ikut berdiskusi di dalam forum diskusi makan akan semakin banyak pula poin yang akan didapatkan ditambah poin dari pengumpulan tugas.

\section{UCAPAN TERIMA KASIH}

Penulis sangat bersyukur kepada Allah SWT karena dapat menyelesaikan jurnal ini dengan lancar, penulis berterima kasih kepada SMP Negeri 1 Krembung karena diperbolehkan data dan tempat diperbolehkan digunakan 
Procedia of Engineering and Life Science Vol. 1. No. 2 Juni 2021

Seminar Nasional \& Call Paper Fakultas Sains dan Teknologi (SENASAINS 2 ${ }^{\text {nd }}$ )

Universitas Muhammadiyah Sidoarjo

dalam pembuatan jurnal ini, dan juga berterima kasih kepada dosen pembimbing, teman-teman, orang tua dan orang-orang yang telah mendukung penulis hingga sampai di titik ini.

\section{REFERENSI}

[1] Tavangarian, D., Leypold, M. E., Nölting, K., Röser, M., \& Voigt, D. (2004). Is e-Learning the Solution for Individual Learning? Electronic Journal of E-Learning, 2(January 2004), 273-280.

[2] Jusuf, H. (2016). Penggunaan Gamifikasi dalam Proses Pembelajaran.

[3] Meyhart, B. S. (2016). Studi Literatur mengenai Gamifikasi untuk Menarik dan Memotivasi: Penggunaan Gamifikasi saat ini dan Ke depan, Studi Literatur - Tugas Seminar 1 PASCASARJANA TEKNIK ELEKTRO JUNI 2016

[4] Ritonga, R. (2019). Sistem Informasi Penjualan Pada Toko R2 Collection Di Rantauprapat Berbasis Web. Jurnal Informatika, 7(3), 120-125.

[5] Hannay, M., \& Newvine, T. (2006). PERCEPTIONS OF DISTANCE LEARNING: A COMPARISON OF ONLINE AND TRADITIONAL LEARNING. In MERLOT Journal of Online Learning and Teaching (Vol. 2, Issue 1).

[6] Ahmad Zakir, 2016. rancang bangun responsive web layout dengan menggunakan bootstrap framework. Jurnal Nasional Informatika dan Teknologi Jaringan. Sekolah tinggi TeknikHarapan Medan.

[7] Marisa, F., \& Yuarita, T. G. (2017). Perancangan Aplikasi Point of Sales (Pos) Berbasis Web Menggunakan Metode Siklus Hidup Pengembangan Sistem. Jurnal Teknologi Dan Manajemen Informatika, 3(2), $167-171$.

[8] Antonius Nugraha Widhi Pratama, 2010, Codeigniter: Cara Mudah Membangun Aplikasi PHP, mediakita Jakarta Selatan.

[9] Jubile Enterprise, 2017, Otodidak MySQL Untuk Pemula, PT Elex Media Komputindo, Jakarta

[10] Tyowati, S., \& Irawan, R. (2017). Implementasi Framework Codeignter Untuk Pengembangan Website Pada Dinas Perkebunan Provinsi Kalimantan Tengah. Jurnal SAINTEKOM, 7(1), 67. 